\title{
Zinchenko 0. DEVELOPMENT OF MECHANISM FOR FORMATION AND ACTIVATION OF TERRITORIAL IMAGE POTENTIAL
}

Об'єктом дослідження є механізм формування та активізації потенціалу регіонального іміджу. В практиці регіонального управління використовується певний алгоритм створення іміджу, однак проблемним моментом залишається відсутність єдиного інструментарію оцінки та залучення потенціалу території до створення ї привабливого образу. Для подолання цієї проблеми автором розроблено механізм формування та активізації потениіалу регіонального іміджу. Цей механізм передбачає залучення до системи іміджмейкингу території всього ї̈ ресурсного потенціалу, дуже широкого інструментарію не тільки управлінської науки, а й соиіології, психології, економічного аналізу, маркетингу.

Для вирішення основних завдань дослідження були використані такі методи, як системний аналіз, структурування, діалектичний метод, теорії управління. За допомогою иих методів запропоновано структуру механізму у виді функціонування систем діагностики потенціалу, формування іміджу та його просування y зовнішньому просторі. Розкрито функиіональний зміст иих систем, розроблено іх інструментарій та методичну базу, які можуть бути використані на різних етапах розробки та просування іміджу. Як основний орієнтир функціонування механізму висунуто інтереси споживачів території, наведено їх характеристику, визначено групу стейкхолдерів, обгрунтовано їх відмінність від споживачів території. Серед базових принципів функціонування механізму виділено принцип прогностичності, поетапності, зворотного зв'язку, продуктивності. Визначено їх прояв в результаті використання механізму.

Розроблений механізм є універсальним, що дає змогу розробити заходи, починаючи від задуму образу території до просування ї̈ иілісного іміджу. Використання механізму в практиці регіонального менеджменту дозволить активізувати зусилля місиевої влади та громадськості щодо розробки та просування іміджу території на загальнодержавному та глобальному економічному просторі. Інструментальні засоби механізму можуть бути використані при діагностиці потениіалу регіонального розвитку та розробиі заходів з територіального маркетингу.

Ключові слова: імідж території, потенціал іміджу, регіональний менеджмент, територіальний маркетинг, система діагностики.

\section{Introduction}

In the conditions of post-industrial development and reform of the economy and public administration in Ukraine, on the basis of decentralization, individual territories regions, settlements become more independent entities. They can independently make decisions and carry out business operations related to the corresponding costs and revenues.

Territories actively manage their resources to increase competitiveness in order to attract investments and the population. Therefore, interest in the development of territories is strengthened both from a scientific and practical point of view.

Image is an extremely important resource both at the state and regional levels. This is due to the exceptional role of information in the competitive struggle of economic and political relations. The image of the territory, its reputation among the domestic and foreign political and business communities become the main factors for promoting national and regional goals, promising projects, the most important competitive advantage for establishing productive relations.

Prerequisites for the formation of the image are various economic, geographical, national, cultural, demographic characteristics of the state system. From the degree of their assessment and consideration in the process of developing the image depends on its validity and objectivity of reflecting public reality.

Therefore, it is relevant to study methodological approaches to the formation and promotion of the image, taking into account the characteristics of the territories, their resource and intellectual potential.

\section{The object of research and its technological audit}

The object of research is the mechanism of formation and activation of the image potential. At the same time, the potential should be understood as a complex of economic, organizational and social factors that provide conditions and form resources (material, intellectual, information) in the region to create and promote its positive image.

The potential of the regional image remains static, unless efforts are made to activate it. This is a purposeful, comprehensive impact on the components of the potential using a certain mechanism.

In the practice of regional management in Ukraine, a model of image formation that involves a certain sequence of stages is common (Fig. 1). 


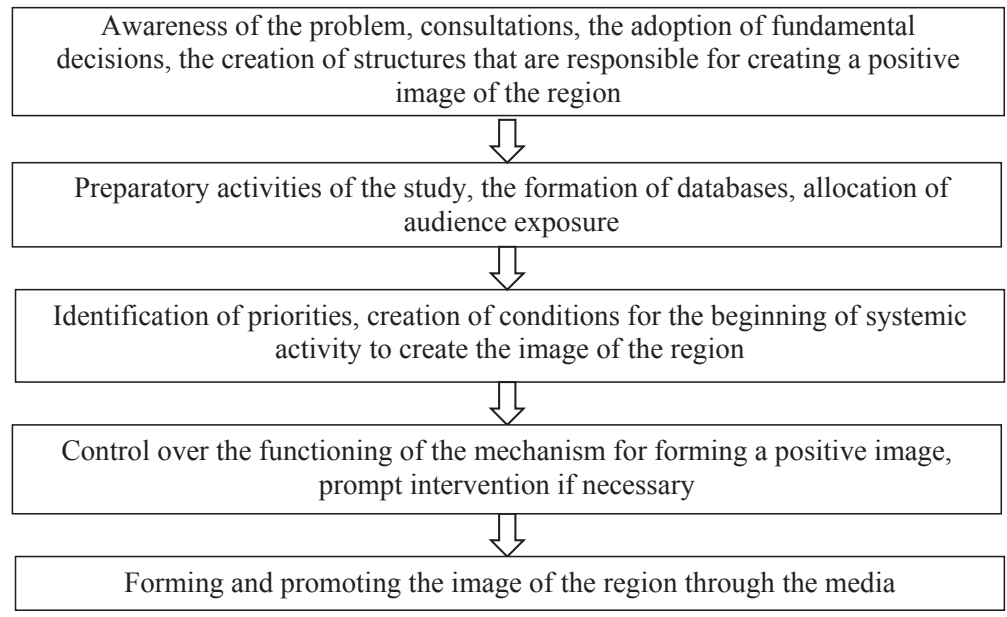

Fig. 1. Algorithm for creating the territorial image

This model has found a comprehensive application in the branding of Ukrainian cities (Kyiv, Odesa, Kharkiv, Dnipro) and given in the programs of forming their image [1]. It should be noted that these territories have a clearly expressed image, long-standing traditions of the community, well-developed brands of producers of products and services.

Following the proposed algorithm makes it possible to use the competitive advantages of territories in promoting their image. However, for other territories with less pronounced characteristics that do not yet have a holistic image in the representation of social groups, this algorithm is not effective, since it does not provide an opportunity to reveal the potential of the image and the prerequisites for its activation. Another significant drawback is the lack of analysis of the interests of the consumers of the territory, which should be taken into account when creating an image for its successful implementation.

\section{The aim and objectives of research}

The aim of research is development of a universal mechanism for the formation and promotion of the image of the territory, which is aimed at revealing and activating the image potential. At the same time, an important characteristic of the algorithm should be universality for regions and settlements with different levels of development.

To achieve this aim, it is important to:

1. Develop a general model mechanism and analyze its main subsystems and their functional content.

2. Offer tools and methodological approaches that can be used at various stages of developing and promoting the image.

3. Establish guidelines and principles for the functioning of the model.

\section{Research of existing solutions of the problem}

Analysis of the scientific literature on the image of the territories allows to outline the following concepts for image formation:

- geopolitical - research of the image from the geographical space point of view, including the brightest and those memorable symbols, signs, images and characteristics of certain territories, countries, regions, label them from the political point of view [2-4];
- branding - reflects the concept of «region (territory) - brand», which is applied if the government, through marketing technologies, influences the image of the state in order to fill it with positive meaning [5-7];

- marketing - in which the region is viewed as a commodity with integrated functional content, and the task of regional and local authorities is influence on the formation of its positive image with the help of marketing technologies [8-10];

- psychological - the image of the territory is examined on two levels: at the first level, psychological mechanisms for the formation of the mental image the image, at the second level, the communication interaction between the image and the social group is explored [11, 12];

- information and communication - the sphere of image formation acts as a system of various information flows, in certain ways organized and broadcast by appropriate information channels by various actors. Within the framework of this approach, the system characteristics of the information political space, methods and technologies of political communication are analyzed [13, 14].

All these approaches can be taken into account when developing the mechanism for the formation and promotion of the image, as they complement the various aspects of it with a new functional content. They make it possible to move away from the «narrow» understanding of it as an object of territorial marketing, to tap the full potential of its activation.

The image arises from the constant associative representation, which was formed under the influence of historical development and the impressions of various contact groups, which reflects the characteristics of the territory in a complex manner. As an instrument of regional management, the image is aimed at ensuring the competitive advantages of the territory and satisfying the interests of its population.

Thus, the results of the analysis allow to conclude that there is no single integrated approach to the formation of the image of the territory. Different schools of economic science consider these processes in different ways, highlighting and highlighting those aspects that are the object of research of these schools 


\section{Methods of research}

The methodological base of the research is:

- systematic approach (in developing a model for building and enhancing the potential of the image);

- structuring (in the study of the elements of the model and their functional content);

- dialectical method (scientific abstraction, means abstraction, rejection of a single, random in the formation of the image, development of a universal approach);

- management theory (when interpreting the functions of image design management).

\section{Research results}

The mechanism of formation and activation of the positive potential of the image assumes the functioning of three systems: a system for diagnosing the potential, the system of image formation and a system for activating its positive potential. Each of the subsystems has its own tools, methods to achieve the tasks, functions in the general mechanism. All of them influence a certain resource base with the aim of transforming it into a final product a positive image, an attractive brand, and in a nationwide and global dimension - a competitive territory (Fig. 2).

At the entrance to the mechanism are the interests of consumers of the territory, that is, those contact audiences who are interested in it. At the same time, this interest manifests itself in different ways: for the population it is the place of residence, for tourists - an interesting object for visiting, for workers - the sphere of labor activity, for investors - promising territory for the implementation of business projects.

Stakeholders and target audiences of the image (its consumers) play different roles in the processes of creating the image. So, stakeholders motivated to activate the image, as it satisfies their interests, they take an active position in the processes of creating and promoting the image. Consumers of the territory may not have a clear interest in this, but use the image «unconsciously», that is, do not take any special action. On them, as on the contact audience, the directed effect of the image. When incentives appear in the target audiences in the promotion of the regional image, they become the category of stakeholders.

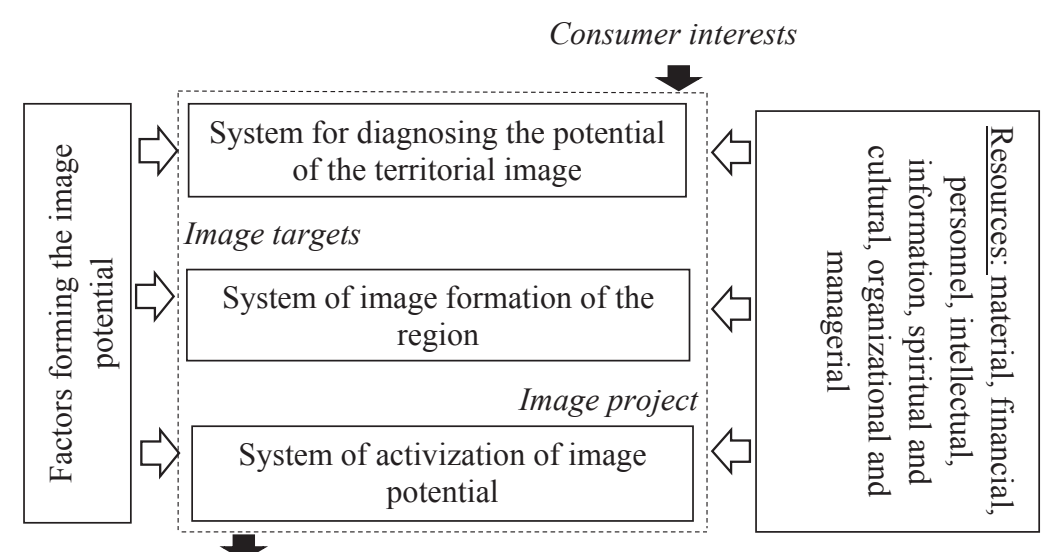

Positive image Attractive brand Competitive territory

Fig. 2. The general scheme of the mechanism for the formation and activation of the potential of the regional image
All the resources of the mechanism can be divided by their nature of origin and scope of application for: - material and technical - natural and resource potential, industrial base, technical equipment, energy resources, regional infrastructure, characterizing the production capacities of the region and ensure the implementation of projects to create an image;

- financial resources of the regional budget, enterprises, population, financial and credit institutions, funds of public organizations that may be involved in the processes of image formation;

- personnel - qualified and unskilled labor, there is a touch of systemic transformation;

- spiritual and cultural - history, cultural heritage, a system of permanent values that will be the basis for the emotional perception of the territory;

- information - a collection of documented and undocumented information in information systems (libraries, archives, data banks, etc.), as well as ways and approaches to working with it. The category is very extensive, since it covers not only the aggregate of data, but also the technological component;

- intellectual - the totality of accumulated knowledge, ideas, competences that have scientific and commercial value and can be used in creating and promoting the image of the territory. This type of resources, although informational in character and related to human resources, is inherently related to the importance of innovative development and the specificity of management approaches, they form a separate group;

- organizational and managerial abilities and capabilities of state and regional authorities, local governments, management of commercial and non-commercial organizations to initiate, organize, direct the creation and distribution of the image. And also to motivate all participants of these processes, to monitor and analyze the results of this activity.

The system for diagnosing the potential of a regional image involves such functions as assessing the potential for regional development, diagnosing the prerequisites for image formation, analyzing the image target audience, assessing the image of the region, and monitoring stakeholder interests (Fig. 3).

Assessment of potential opportunities includes monitoring of all elements of regional potential and their correlation to the satisfaction of the target audience. This is the starting point of strategic analysis, which determines the types of necessary resources, the degree of their availability, the required volume and quality characteristics.

Diagnostics of the prerequisites for the formation of the image involves an analysis of the factors influencing the processes of its creation and promotion (economic, political, social, environmental, security, etc.), and assesses the state of all systems of socioeconomic development. The system of regional management is considered separately, the internal resource of authority, the degree of its mobilization, the correctness of the development of the region, readiness for structural changes, competence and awareness are estimated. 


\section{Consumer interests}

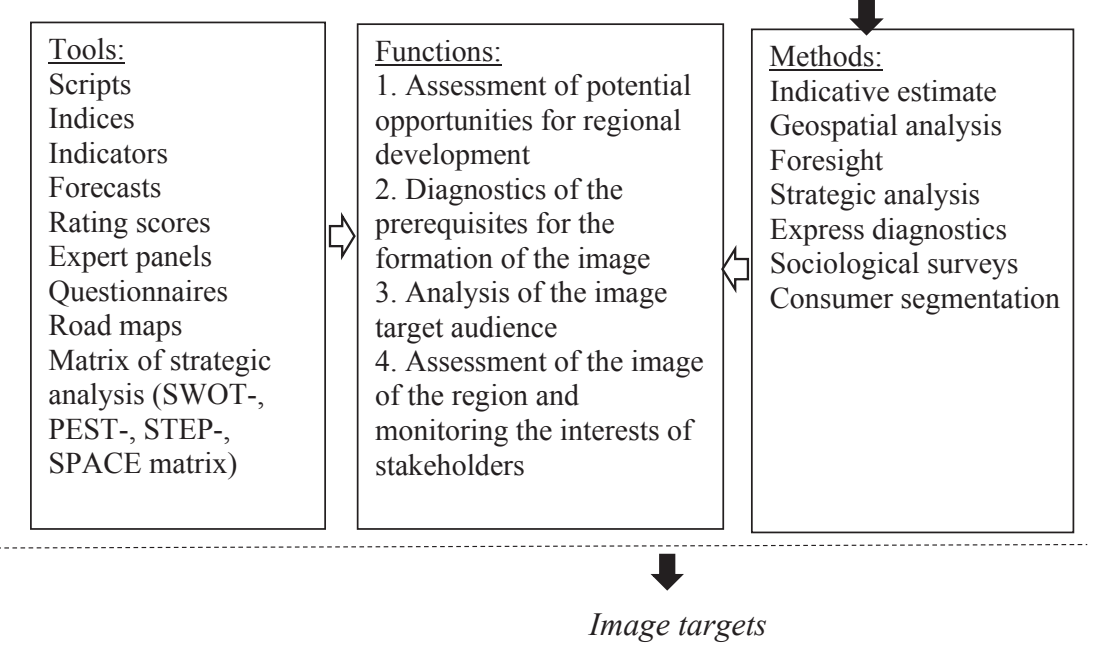

Fig. 3. System for diagnosing the potential of a regional image

The analysis of the image audience is aimed at identifying and segmenting all consumers of the regional image: - population of the region: gender-age composition, educational and cultural level, professional characteristics of the population, its loyalty to power, satisfaction with living and working conditions;

- business structures of the region: the level of their business activity, their involvement in the processes of regional management, interest in economic and managerial reforms;

- potential investors: their interest in business projects within the region, the volume of investment, the possibility of their involvement in the regional economy; - tourists: their interest in visiting the territory, incentives for travel, age and sex composition, educational and cultural level, belonging to a certain territorial community (region, country);

- labor migrants: their professional qualification, sex-age composition, level of education, motivation for employment at the enterprises of the region;

- bodies of state power and administration of other regions: the amount of subventions, grants from the state power, support for regional projects and programs, interregional cooperation, its spheres and content of interaction.

An assessment of the attitude of these groups to the region is being conducted, problems of positive perception are established, conclusions about reputation are made. This creates the image of the region, due to the successful actions of all interested parties becomes a style. Stakeholders are defined, the degree of their interest, the main motives and incentives, the possibility of engaging in the processes of creating and promoting the image.

The image formation system assumes the following functions (Fig. 4):

- identification of strategic priorities;

- definition of territory in the national and global space;

- formation of the desired image and strategy for its promotion, branding of the region;

- formation of a complex of promotion communication.

The definition of the strategic priorities is a transitional link between the diagnostic system and the image creation system, since priorities are established through strategic analysis, which is the main diagnostic tool, but specific activities are developed on the basis of priorities.

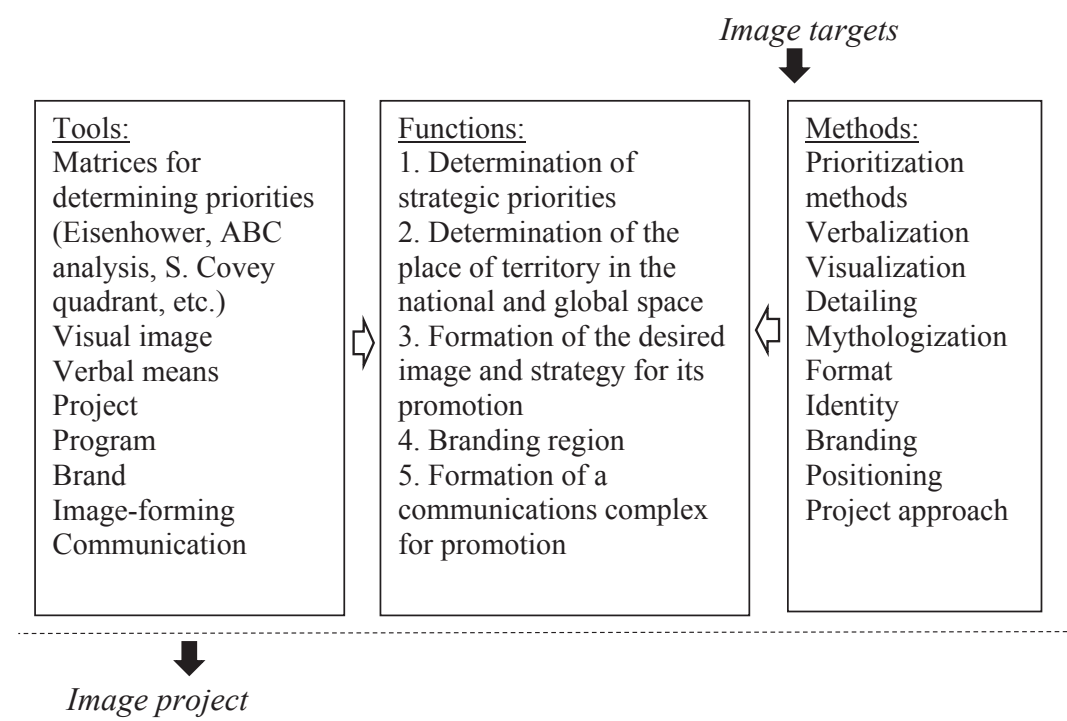

Fig. 4. System of image formation of the region 
Priority is the expression of the goal, its reflection in a certain space, taking into account the perception of a particular audience. Priority forms a system of tasks for the subjects of the image, they lay the foundation for the basic characteristics of the image.

The definition of the territory in the national and global space is based on the diagnosis of its current state and place in the ratings of regional development. This function is understood as the establishment of a specific position of the region in the territorial division of labor, taking into account its specialization, the share of revenues in the state budget, the level of investment attractiveness, social development.

Thus, the status of the region is assessed. Global positions of the region are determined on the basis of international cooperation, its transnationalization, activation of foreign economic activity of business structures, labor mobility.

The real positions of the region and the expectations of target audiences form the image of the region with the help of such tools as verbalization, visualization, detailing, mythologization. A special place is occupied by the identity - the creation of symbols that are associated with the region and help to create a holistic impression in the target audiences.

The promotion system translates the desired image into the «image» category, which can be commercialized and serve specific goals of regional management. At this stage, promotion strategies are developed that define the main guidelines and detail the actions in the following areas:

- attraction of business from other territories: can be used as preferences of the authorities, transparency of regulation of entrepreneurial activity, and the level of innovative development, international partnerships, high indicators of the quality of life of the population producers and consumers of the regional product;

- content and expansion of the existing business, can be expressed in a dialogue between business leaders and representatives of regional authorities. The result of this is the involvement of business in the development of marketing strategies in the region, the integration of the efforts of business structures and regional authorities in overcoming the problems of socio-economic development; - stimulation of small business development and assistance to newcomers as carriers of innovative ideas and high business activity;
- increasing the volume of exports and attracting foreign investment: the region can gain an advantage by becoming known as a producer of high-quality goods or services, therefore it is necessary to promote brands of products in the region;

- development of tourism and creation of tourist destinations;

- involvement of a skilled workforce through the creation of an enabling system of employment and the provision of decent working conditions.

The formed image is transformed into a regional brand, which is the highest manifestation of emotional consumer preferences. Brand creation - branding - involves an image expressed in the form of presentation, which can be positioned on the national and global markets.

Formation of a complex of communications promoting the image is aimed at creating appeals to consumers, selecting ways and channels for promotion, assessing the possible degree of their workload, identifying sources of data on the processes of image perception. The effectiveness of the design of information exchange will depend on the success of the whole process of promotion.

The system of image formation is based on various and in nature, and the content of the methodology, the arsenal of tools they use, is also quite branched. Since the ultimate goal of the system is the creation of a regional image project, after consideration and discussion by the regional authorities and the public is accepted for execution, a particular place among the methodologies is given to the project approach.

The project approach can take into account both the expectations of social groups and the uncertainty of the environment in which the image is realized.

Also, this approach has many rapid response tools to provide the ability to predict scenarios of future events, form strategies and develop processes for their implementation [15].

The system of activating the image potential requires the following functions (Fig. 5):

- minimizing the risks of rejecting the image;

- implementation of projects to create an image;

- formation of favorable conditions for activating the image;

- analysis of the effectiveness of the use of image potential.

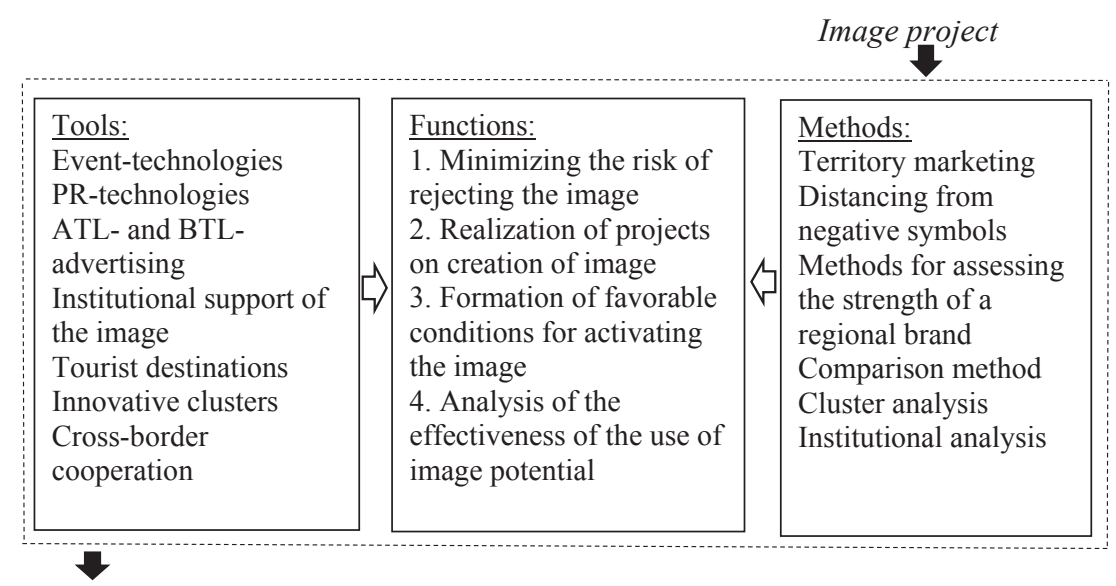

Positive image Attractive brand Competitive territory

Fig. 5. System for enhancing the potential of the image of the region 
Often, a territorial image is formed in the absence of sufficient information and experience of the target audience. In this case, the basis of the image is based on mass stereotyped ideas (and sometimes even mistakes), facts drawn from the media, literary, cinematographic and other sources.

However, an artificially created image may not reflect, for example, the main social and economic characteristics, problems and contradictions of the territory. Outside of its attention can remain real principles and methods of doing business, the peculiarities of life of the population, the impact of the economy of the territory on the environment. Conversely, sometimes some real (or existed earlier, and sometimes even fictional) feature of the region, or its settlement in a hypertrophied or distorted form, can be given as the main characteristic of the object.

The task that faces the promotion system is minimization of the risks of rejection. This is possible due to the analysis of the expectations of target audiences from regional development and the consideration of these facilities when developing and implementing marketing policies.

The task of territorial marketing is influence, through a certain set of tools and tools, the opinion, position and behavior of internal and external consumers, and to stimulate contacts between them.

Marketing of the territory provides for a comprehensive improvement of the territory, based on its three main purposes:

- territory - as a place of residence;

- territory - as a place of rest (natural environment);

- territory - and as a place of management (invest-

ment of production, extraction and processing).

Territorial marketing involves: branding the region, public relations, promotion, event marketing, advertising of regional projects.

The regions face the challenge of creating an effective marketing promotion strategy that determines the concept of positioning, shaping an attractive image, promotion tools, expanding a loyal audience and developing the market. In addition, it is necessary to develop a brand strategy, a strategy to enter existing markets (penetration strategy), a distribution strategy and communications. It is important to use the approach developed during the seminars and working groups, take into account the views of the stakeholders.

Effective functioning of the system of activating the potential of the regional image allows to increase the awareness of the target audience about the region, events and product offer, to create the attractiveness of the resources, living conditions and business activity concentrated on its territory. It is aimed at systematization and consolidation of efforts to create a unified promotion strategy, to form a positive perception of the region.

Tools for creating a territorial image in the traditional sense include a set of marketing communications tools. Such tools as advertising, public relations, direct marketing. The image of the region can be considered as a commodity in this case, according to the goals of implementing image creation tools, creation, support and development of interest in the region arise.

Methods of promotion in the context of territorial marketing include the following:

- definition of mechanisms for communicating positive information to target audiences: public relations, promotion campaigns using ATL advertising (advertising in the press, television, radio and cinema), BTL advertising (forums, exhibitions, presentations);

- purposeful dissemination of information on unique characteristics and quality of goods, infrastructure development, favorable investment climate, tourist attractiveness and positive events, successes, people, etc., occurring;

- use of event technologies as a means of organizing outstanding economic, scientific, cultural events in the region;

- development of the region's image as a set of brands of the region's production;

- organization of monitoring of the image of the region and neutralization of negative stereotypes.

A carefully designed company to promote the image can be defeated if there are negative associations with the territory in the target audiences (for example, related to anthropogenic disaster, crimes against humanity, impoverishment of the population, lack of democratic freedoms, corrupt government, etc.). Therefore, the formation of favorable conditions for activating the image is impossible without distancing from negative symbols and strengthening the positive characteristics of the region. Effective tools in this case are the transfer of the attention of the audience to another object (manipulation) and propaganda.

\section{SWOT analysis of research results}

Strengths. Strengths of the proposed mechanism are its versatility and the ability to use when forming the image of a large region and a small town. Complexity of the mechanism allows to develop measures, starting from the idea of the territorial image to promote its holistic image.

Weaknesses. Negative aspects of the mechanism are weak consideration of environmental factors that can radically affect the results of the introduction of the image. This sets new directions for further research and the possibility of improving the mechanism by developing a factor analysis module.

Opportunities. The possibilities of applying the mechanism are broad: from the development of image policy at the level of a particular locality to the formation of a strategy for the development of regions. The tools of the mechanism can be used to diagnose the development potential and develop measures for territorial marketing in various economic systems, taking into account a certain regional specifics.

Threats. Threats to the use of the mechanism are the possibility of using biased information when developing solutions for image formation. High risks of counteraction of the external environment of application of toolkit of the mechanism are also high.

\section{Conclusions}

1. The mechanism of formation and activation of the potential of the regional image realizes the efforts of both regional authorities and the society to promote the region in the national space. The developed mechanism includes subsystems that consistently reflect the algorithm for the formation of the image: from design and delivery to a specific consumer. It is important that at the entrance to the mechanism are precisely the interests of consumers of the territory, provides a high degree of perception of 
the image by all target groups. The system of diagnostics of the mechanism allows to allocate the priorities of the image and to compare them with the potential for its development. The system of image formation is aimed at creating the desired image and its branding, taking into account the peculiarities of the region and the possibilities of communicative means. The system of activating the potential of the image implies the realization of its project in the conditions of a changing environment.

2. Each of the subsystems has its own tools, methods for achieving the assigned tasks are methods:

- economic analysis;

- strategic management;

- territorial marketing;

- sociological research;

- psychology.

Only in combination of various instruments it is possible to success in realizing the interests of the stakeholders and effectively promoting the image of the region.

3. All systems of the mechanism are oriented to the transformation of regional potential into a final product a positive image, an attractive brand, and in a nation-wide and global dimension - a competitive territory.

The principles of the mechanism are:

- predictability principle, oriented to the forecast state

of the object;

- principle of staged, which involves a transition from design to real action and allows you to ultimately achieve your goals;

- feedback principle, which allows to correct actions, obtain information on the results of design procedures; - productivity (efficiency) principle focuses on the result.

Perception of the image as a regional project allows more mobile management of the processes of its creation and promotion, contributes to a more efficient distribution of the roles and statuses of all participants, and expands the tools for its formation and implementation.

\section{References}

1. Semchenko O. A. Imidzhmeikinh rehioniv Ukrainy: praktychni napratsiuvannia // Osvita rehionu. 2013. Issue 1. P. 174-179.

2. Knight D. B. Identity and Territory: Geographical Perspectives on Nationalism and Regionalism // Annals of the Association of American Geographers. 1982. Vol. 72, Issue 4. P. 514-531. doi: http://doi.org/10.1111/j.1467-8306.1982.tb01842.x
3. C-IMAGE: city cognitive mapping through geo-tagged photos Liu L. et. al. // GeoJournal. 2016. Vol. 81, Issue 6. P. 817-861. doi: http://doi.org/10.1007/s10708-016-9739-6

4. Salesses P., Schechtner K., Hidalgo C. A. The Collaborative Image of The City: Mapping the Inequality of Urban Perception // PLoS ONE. 2013. Vol. 8, Issue 7. P. e68400. doi: http://doi.org/10.1371/journal.pone.0068400

5. Rousseau M. Re-imaging the City Centre for the Middle Classes: Regeneration, Gentrification and Symbolic Policies in 'Loser Cities' // International Journal of Urban and Regional Research. 2009. Vol. 33, Issue 3. P. 770-788. doi: http:// doi.org/10.1111/j.1468-2427.2009.00889.x

6. Jose M. A., Vila-López T. How can mega events and ecological orientation improve city brand attitudes? // International Journal of Contemporary Hospitality Management. 2014. Vol. 26, Issue 4. P. 629-652. doi: http://doi.org/10.1108/ ijchm-03-2013-0117

7. Harcup T. Re-imaging a post-industrial city: The Leeds St Valentine's Fair as a civic spectacle // City: analysis of urban trends, culture, theory, policy, action. 2010. Vol. 4, Issue 2. P. 215-231. doi: http://doi.org/10.1080/13604810050147839

8. Balibrea M. P. Urbanism, culture and the post-industrial city: Challenging the 'Barcelona model' // Journal of Spanish Cultural Studies. 2010. Vol. 2, Issue 2. P. 187-210. doi: http:// doi.org/10.1080/14636200120085174

9. Liu Y., Chen C. The effects of festivals and special events on city image design // Frontiers of Architecture and Civil Engineering in China. 2007. Vol. 1, Issue 2. P. 255-259. doi: http:// doi.org/10.1007/s11709-007-0032-0

10. Romão J., Guerreiro J., Rodrigues P. Territory and Sustainable Tourism Development: a Space-Time Analysis on European Regions // Region. 2017. Vol. 4, Issue 3. P. 1-17. doi: http:// doi.org/10.18335/region.v4i3.142

11. Kim H., Chen J. S. Destination image formation process: a holistic model // Journal of Vacation Marketing. 2015. Vol. 22, Issue 2. P. 154-166. doi: http://doi.org/10.1177/1356766715591870

12. Smith A. Conceptualizing City Image Change: The «Re-Imaging» of Barcelona // Tourism Geographies. 2005. Vol. 7, Issue 4 P. 398-423. doi: http://doi.org/10.1080/14616680500291188

13. Eli A. Media Strategies for Improving an Unfavorable City Image // Cities. 2004. Vol. 21, Issue 6. P. 471-479. doi: http:// doi.org/10.1016/j.cities.2004.08.005

14. Shao Z., Li D. Image City sharing platform and its typical applications // Science China Information Sciences. 2011. Vol. 54, Issue 8. P. 1738-1746. doi: http://doi.org/10.1007/ s11432-011-4307-7

15. Zinchenko O. Project approach to creating the regional image // European Journal of Management Issues. 2017. Vol. 25, Issue 3-4. P. 176-183. doi: http://doi.org/10.15421/191721

Zinchenko Olha, PhD, Associate Professor, Department of Management and Tourism Business, Oles Honchar Dnipro National University, Ukraine, e-mail: ol-zinchenko@ukr.net, ORCID: http://orcid.org/ 0000-0002-5414-7839 